日植病報 $47: 58-67$ (1981)

Ann. Phytopath. Soc. Japan $47: 58-67$ (1981)

\title{
Characterization of Resistance in Rice to Bacterial Blight
}

\author{
T. W. MeW*, C. M. VerA CRUZ* and R. C. ReYes*

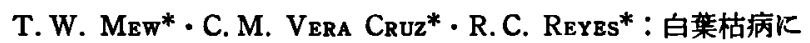 \\ 対するイネ品種抵抗性発現の変動
}

\begin{abstract}
Infection from strains of Xanthomonas campestris pv. oryzae on IR8, IR20 and IR1545 by the leaf clipping, pin-pricking and spray methods of inoculation suggested that neither lesion length nor disease score were affected. The incubation period was varied by methods of inoculation, but not by varietal resistance. Breeding lines derived from TKM 6 for Xa4 and DZ192 for $x a 5$ sources of resistance were consistent with respective bacterial strains of the same virulence group, at maximum tillering stage of plant growth. The resistance was not complete. Significant differences in virulence between group 1 strains to TKM 6 and its derivatives and group 2 strains to TKM 6, DZ192 and their derivatives were observed. The effect of leaf age, as well as plant age, to infection varied from young to old, but the significant lesion length was observed only in compatible rice cultivar and bacterial strain combinations. The lesion length of breeding lines having "adult plant" resistance, such as IR1695 and IR944, gradually decreased from vegetative stage to reproductive stage against strains of all virulence groups evaluated. Lesion length of cultivars of moderate susceptibility comparable to partial resistance, was decreased significantly when inoculum dosage was lower, while the lesions on lines with adult plant resistance were not different from IR 8, the check variety.
\end{abstract}

(Received October 7, 1980)

\section{Introduction}

Bacterial blight of rice caused by Xanthomonas campestris pv. oryzae (Ishiyama, 1922) Dye, 1978, is one of the most serious rice diseases in tropical Asia. Some bactericides have been formulated in Japan for the control of the disease, but none are highly effective or economically feasible in tropical Asia. As a result, the use of resistant cultivars and cultural management have been widely recommended or practiced in Asia ${ }^{11)}$. Resistance breeding for bacterial blight in rice is, therefore, a major component of varietal improvement of many national programs in Asia.

Resistance of both japonica and indica rice cultivars has been studied ${ }^{11}$. In Japan, varieties have been classified according to their resistance to bacterial groups ${ }^{3)}$ sensu races of Van der Plank ${ }^{15}$ ). Wakimoto first confirmed ${ }^{14}$ ) that resistance of some rice varieties varied when they were evaluated at the seedling stage.

Resistance expression of certain cultivars was more distinct in adult plants than during the tillering stage ${ }^{1)}$. Still, many rice cultivars have been analyzed for inheritance of bacterial blight resistance and genes for resistance have been identified ${ }^{2,10,12,18,14)}$. 
Generally, the resistance is conditioned by major genes in those cultivars under investigation ${ }^{1,11,12,13)}$. The resistance expression varies.

The phenomenon could be due to the lack of complete resistance in those cultivars under study. It also could be related to the lack of distinct specialization in pathogenicity of the bacterium. More than likely, as pointed out by Ezuka and Horino ${ }^{3}$ it might be attributed to the incomplete expression of vertical resistance of rice plants tested at different ages. Ezuka et al., ${ }^{4}$ and Horino and Yamada $^{6}$ ) showed the virulence of bacterial strains also varied when they were evaluated at the seedling stage.

Bacterial blight resistance research at IRRI, in collaboration with national scientists, has identified and developed rice cultivars or breeding lines with "broad spectrum" resistance through multi-location testing or rice with specific resistance. Different genes for resistance to bacterial blight disease also have been identified in more than 200 selected rice entries $^{10,11,12)}$ through inheritance study.

This report describes the influences of plant and leaf ages on the expression of resistance of rice varieties carrying $X a 4, x a 5$ and other genes for resistance (R-genes) to strains of two major virulence groups of $X$. campestris pv. oryzae.

\section{Materials and Methods}

Rice entries. During the last 5 years, over 30,000 rice accessions from IRRI's germplasm collection were evaluated for their resistance or susceptibility to virulence of the most common strains exemplified by PXO61. About 2,000 tested were resistant to this strain, which is virulent only to rice with no genes for resistance. This includes such varieties as IR8 and more recently Cas 209 (Mew, unpublished data) in the Philippines. Rices included in the present study were chosen from the 2,000 entries.

Rice plants generally were pot-grown in soil fertilized with $\mathrm{N}-\mathrm{P}-\mathrm{K}$ at the rate of 120 60-60 kg per ha. A basal application of $90 \mathrm{~kg} \mathrm{~N} /$ ha was mixed thoroughly with $60 \mathrm{~kg}$ each of $\mathrm{P}$ and $\mathrm{K}$, then the soil was potted. Another $30 \mathrm{~kg} \mathrm{~N}$ was applied at booting stage, or whenever it was applicable during the study.

To determine the effect of plant age, rice entries were seeded at different time intervals in seedboxes, then transplanted into pots. Inoculation was done at the same time. Leaf age was determined by leaf position. They fully expanded leaf immediately below the unfolded new leaf was designated as $\mathrm{LI}$; the two subsequent leaves were designated as L2 and L3, respectively.

Inoculum preparation and inoculation. Four strains of $X$. campestris pv. oryzae, representing bacterial groups virulent to cultivars carrying specific genes for resistance in the Philippines (exemplified by PXO61 for group 1, PXO86 for group 2, PXO79 for group 3 and PXO71 for group 4), were used throughout the study unless otherwise stated. The inoculum of each strain was prepared by culturing the bacteria on the slant of Wakimoto's medium. Four-day-old cultures were suspended in sterile, distilled water and adjusted to a density of ca. $10^{9} \mathrm{cells} / \mathrm{ml}$.

Three methods of inoculation were evaluated on IR8, IR20 and IR1545-339 (referred to as IR1545) using different strains of the same inoculum density. Leaf-clipping was done by dipping scissors into the bacterial suspension then cutting 1-2 cm from the leaf tips. For the pin-prick method an improvised double-needle prick instrument was used. 
Instrument needles were infested with the bacterial suspension, then punched gently into both sides of the midrib at the central portion of a leaf. The spray method of inoculation was done by spraying the bacterial suspension uniformly on all leaves. The plants were incubated in a moist chamber for $24 \mathrm{hr}$, then placed in the greenhouse bench for observation.

Usually 10 to 20 leaves per replication were inoculated with a strain. Split plot and split-split-plot designs ${ }^{5}$ ) were used for 2- and 3-factor experiments, respectively. Disease was measured according to either lesion length, where lesion development was uniform, or scales according to the Standard Evaluation Systems for Rice (SES) (IRRI, 1975).

\section{Results}

\section{Methods of inoculation}

Disease scores of the three rice cultivars were not affected by the three methods of inoculation using the three strains with specific virulence (Table 1). Regardless of methods of inoculation, PXO61 was more virulent to IR8 than to IR20 and IR1545. Likewise, PXO79 was more virulent to IR8 and IR20 than to IR1545. PXO71 was more virulent to IR8 and IR1545 than to IR20. The lesion length measurement was consistent with the scale used. The incubation period varied from 3 to 5 days based on the clipping method of inoculation, 4 to 6 days by pin-pricking, and 6 to 8 days by spraying the inoculum on the plants (Table 1).

\section{Reaction of rice having $R-g e n e s ~ X a 4$ and $x a 5$ for resistance}

IR8, which does not carry any functional gene for resistance to bacterial blight in the Philippines, showed susceptible reaction to all strains of the tested virulence groups 1 and 2 (Table 2). One breeding line, IR1545-179, was susceptible to all the strains. Cultivars having the $\mathrm{Xa4}$ gene for resistance were resistant to all strains belonging to virulence group 1, while susceptible to strains belonging to group 2. Rice cultivars or breeding lines carrying the R-gene $x a 5$ were resistant to strains of the two groups (Table 2). The

Table 1. Reactions of rice having different resistance genes to strains of specific virulence as affected by methods of inoculation

\begin{tabular}{|c|c|c|c|c|c|c|c|}
\hline \multirow{2}{*}{$\begin{array}{l}\text { Method of } \\
\text { inoculation }\end{array}$} & \multirow{2}{*}{ Cultivar } & \multicolumn{3}{|c|}{ Incubation period (day) } & \multicolumn{3}{|c|}{ Disease score ${ }^{\text {s) }}$} \\
\hline & & PXO61 & PXO79 & PXO71 & PX061 & PXO79 & PX071 \\
\hline \multirow[t]{3}{*}{ Leaf clipping } & IR8 & $3-4$ & $3-4$ & $3-4$ & $9(22)$ & $9(16)$ & $9(27)$ \\
\hline & IR20 & $3-5$ & $3-5$ & $3-5$ & $1(3)$ & $7(13)$ & $3(4)$ \\
\hline & IR1545 & $4-5$ & $4-5$ & $3-4$ & $1(3)$ & $1(2)$ & $7(13)$ \\
\hline \multirow[t]{3}{*}{ Pin-prick } & IR8 & $4-6$ & $4-6$ & $4-6$ & $9(30)$ & $9(26)$ & $9(34)$ \\
\hline & IR20 & $4-6$ & $4-6$ & $4-6$ & $1(1)$ & $9(24)$ & $1(2)$ \\
\hline & IR1545 & $4-6$ & $4-6$ & $4-6$ & $1(3)$ & $1(2)$ & $9(18)$ \\
\hline \multirow[t]{3}{*}{ Spray } & IR8 & $6-8$ & $6-8$ & $6-8$ & 9 & 9 & 9 \\
\hline & IR20 & $8+$ & $6-8$ & $6-8$ & 1 & 7 & 3 \\
\hline & IR1545 & $8+$ & $6-8$ & $8+$ & 1 & 1 & 9 \\
\hline
\end{tabular}

a) Based on 1-9 scales on lesion areas over leaf area, $1=$ less than $1 \%, 9=$ more than $50 \%$. Figures in the parenthesis denote lesion length in $\mathrm{cm}$. 
Table 2. Interactions between rice cultivars/breeding lines having specific $\mathrm{R}$-genes, $\mathrm{Xa4}$ and $x a 5$ for bacterial blight resistance and strains of specific virulence of Xanthomonas campestris pv. oryzae in the Philippines

\begin{tabular}{|c|c|c|c|c|c|c|c|c|c|c|}
\hline \multirow{3}{*}{ Cultivar/line } & \multicolumn{10}{|c|}{ Disease score $^{\mathrm{d})}$ (lesion length, $\mathrm{cm}$ ). } \\
\hline & \multicolumn{5}{|c|}{ Virulence group 1} & \multicolumn{5}{|c|}{ Virulence group 2} \\
\hline & PXO52 & PX061 & PX084 & PX085 & PXO80 & PXO63 & PXO79 & PXO82 & PXO87 & PXO88 \\
\hline \multicolumn{11}{|l|}{ S-check } \\
\hline IR8 & $9(23)$ & $9(26)$ & $9(27)$ & $9(26)$ & $7(12)$ & $9(25)$ & $9(26)$ & $9(24)$ & $9(27)$ & $9(28)$ \\
\hline IR1545-179 & $9(26)$ & $9(27)$ & $9(29)$ & $9(26)$ & $9(26)$ & $9(28)$ & $9(28)$ & $9(26)$ & $9(26)$ & $9(27)$ \\
\hline \multicolumn{11}{|l|}{ R-gene, $X a 4$} \\
\hline TKM6 ${ }^{(b)}$ & $2(4)$ & $1(3)$ & $2(4)$ & $1(3)$ & $1(3)$ & $9(15)$ & $9(18)$ & $9(19)$ & $7(13)$ & $9(16)$ \\
\hline IR20 & $3(5)$ & $2(4)$ & $2(4)$ & $2(4)$ & $1(3)$ & $9(19)$ & $9(20)$ & $9(20)$ & $9(21)$ & $9(19)$ \\
\hline IR40 & $2(4)$ & $2(4)$ & $2(4)$ & $2(4)$ & $2(4)$ & $9(20)$ & $9(20)$ & $9(19)$ & $9(19)$ & $9(19)$ \\
\hline \multicolumn{11}{|l|}{ R-gene, $x a 5$} \\
\hline $\mathrm{DZ192}$ & $1(2)$ & $1(2)$ & $1(2)$ & $1(2)$ & $1(2)$ & $1(2)$ & $1(3)$ & $1(3)$ & $1(3)$ & $1(2)$ \\
\hline IR1545-339 & $2(4)$ & $1(3)$ & $1(3)$ & $1(2)$ & $1(3)$ & $1(3)$ & $2(4)$ & $1(3)$ & $1(3)$ & $2(4)$ \\
\hline IR4563-52 & $2(4)$ & $2(4)$ & $2(4)$ & $1(3)$ & $1(3)$ & $2(4)$ & $2(4)$ & $2(4)$ & $2(4)$ & $2(4)$ \\
\hline
\end{tabular}

a) Susceptible check, no functional genes for resistance to the strains under study.

b) Donor for the R-gene $\mathrm{Xa4}$.

c) Donor for the R-gene $x a 5$.

d) Based on a disease scale 1 to $9: 1=$ less than 1\% lesion area over leaf area, $9=0$ over $50 \%$.

disease scores ranged from 1 to 3 of the SES.

\section{Effect of leaf age}

Preliminary results indicated that unfolded, immature leaves of a cultivar varied in response to infection by $X$. campestris pv. oryzae. Subsequent experiments on the effect of leaf age were, therefore, based on fully expanded leaves of different plant ages.

When a strain was virulent to a cultivar, the disease reaction of the different leaf ages was not changed, although slightly different in lesion length (Tables 3 and 5). Likewise, on a rice cultivar-bacterial strain combination with a resistant reaction, the lesion length was not affected by leaf age. The four strains that exemplified virulence of the four groups of $X$. campestris pv. oryzae in the Philippines initiated lesion length on IR8 comparable to that of the leaves ranging from old to young on IR8 (Table 3). PXO61 caused shorter lesions on IR40 and the reaction was scored with 3 to 4 falling in the range of moderate resistance. On IR8, the disease reaction caused by PXO61 was scored 9 on all leaf ages of 40-day-old plants. On the other hand, IR1545 was more resistant to PXO61, PXO64 and PXO79, but susceptible to PXO71 (Table 3). The disease reaction was consistent on all ages of the leaves.

Different leaf ages of 45-day-old IR8 and IR1545 were inoculated with PXO61 and PXO71. They were subjected to a growth room (max./min. temp. of $29 \mathrm{C} / 21 \mathrm{C}$ and a R. H. at $70 \%$ ) and greenhouse (R. H. higher than $70 \%$ ) conditions. Lesion lengths initiated by both strains in all leaf ages of IR8 were insignificantly different under conditions where the plants were grown (Table 4). The resistance of IR1545 to PXO61 was similar. PXO71 was virulent to IR1545 although shorter lesion length was induced on older leaves. 
Table 3. Effect of leaf position of rice cultivars having specific genes for resistance and susceptibility to strains of Xanthomonas campestris pv. oryzae with different virulence at $\mathbf{4 0}$ days after sowing

\begin{tabular}{lccccc}
\hline \multirow{2}{*}{$\begin{array}{c}\text { Cultivar } \\
\text { Leaf }\end{array}$} & \multicolumn{4}{c}{ Lesion $(\mathrm{cm})^{\mathrm{b}}$} \\
\cline { 2 - 6 } position & PXO61 & PXO64 & PXO79 & PXO71 \\
\hline IR8 & L1 & $9(24.1) \mathrm{a}$ & $9(19.3) \mathrm{a}$ & $9(21.2) \mathrm{a}$ & $9(30.6) \mathrm{a}$ \\
& L2 & $9(21.9) \mathrm{a}$ & $9(16.7) \mathrm{a}$ & $9(19.4) \mathrm{a}$ & $9(29.4) \mathrm{a}$ \\
IR40 & L3 & $9(21.2) \mathrm{a}$ & $9(16.1) \mathrm{a}$ & $9(20.0) \mathrm{a}$ & $9(26.9) \mathrm{a}$ \\
& L1 & $4(7.1) \mathrm{a}$ & $9(22.0) \mathrm{a}$ & $9(17.6) \mathrm{a}$ & $7(9.7) \mathrm{a}$ \\
& L2 & $3(5.4) \mathrm{a}$ & $9(22.1) \mathrm{a}$ & $9(18.5) \mathrm{a}$ & $6(7.6) \mathrm{a}$ \\
IR1545-339 & L3 & $3(6.4) \mathrm{a}$ & $9(19.3) \mathrm{a}$ & $9(18.4) \mathrm{a}$ & $6(7.8) \mathrm{a}$ \\
& L1 & $3(3.7) \mathrm{a}$ & $3(4.1) \mathrm{a}$ & $3(3.9) \mathrm{a}$ & $9(19.2) \mathrm{a}$ \\
& L2 & $2(2.7) \mathrm{a}$ & $2(3.0) \mathrm{a}$ & $3(3.3) \mathrm{a}$ & $9(18.0) \mathrm{ab}$ \\
& L3 & $3(3.1) \mathrm{a}$ & $3(3.1) \mathrm{a}$ & $3(3.7) \mathrm{a}$ & $9(14.2) \mathrm{a}$ \\
\hline
\end{tabular}

a) L1 denotes fully expanded leaf next to an unfolded new leaf, while L2 and L3 follow the order descending from $\mathrm{Ll}$.

b) For each cultivar under bacterial strain, means of any two leaf positions followed by a common letter are not significantly different at $5 \%$ level by LSD.

Table 4. Bacterial blight lesion development caused by strains of Xanthomonas campestris pv. oryzae on different ages of leaves of IR8 and IR1545 grown in different conditions

\begin{tabular}{|c|c|c|c|c|c|}
\hline \multirow{3}{*}{ Environment } & \multirow{3}{*}{$\underset{\text { position }^{\text {b) }}}{\text { Leaf }}$} & \multicolumn{4}{|c|}{ Lesion $(\mathrm{cm})^{\mathrm{c})}$ on } \\
\hline & & \multicolumn{2}{|c|}{ IR 8} & \multicolumn{2}{|c|}{ IR 1545} \\
\hline & & PXO61 & PXO71 & PXO61 & PXO71 \\
\hline \multirow[t]{3}{*}{ Growth room ${ }^{\text {n) }}$} & L1 & $19.6 \mathrm{a}$ & $21.4 \mathrm{a}$ & $2.2 \mathrm{a}$ & $11.5 \mathrm{a}$ \\
\hline & L2 & $19.2 \mathrm{a}$ & $20.8 \mathrm{a}$ & $1.9 \mathrm{a}$ & $10.8 \mathrm{ab}$ \\
\hline & L3 & $17.7 \quad b$ & $21.0 \mathrm{a}$ & $1.7 \mathrm{a}$ & $10.2 \mathrm{~b}$ \\
\hline \multirow[t]{3}{*}{ Greenhouse } & L1 & $19.5 \mathrm{a}$ & $24.0 \mathrm{a}$ & $2.2 \mathrm{a}$ & $13.2 \mathrm{a}$ \\
\hline & $\mathrm{L2}$ & 17.9 b & $23.6 \mathrm{a}$ & $2.0 \mathrm{a}$ & $11.2 \mathrm{~b}$ \\
\hline & L3 & $17.4 \mathrm{~b}$ & $20.4 \quad$ b & $1.5 \mathrm{a}$ & $9.5 \quad \mathrm{c}$ \\
\hline
\end{tabular}

a) Day/night temperature: $29 / 21 ;$ R. H. $=70 \%$.

b) $\mathrm{L} 1=$ fully expanded leaves immediately below the unfolded new leaf of a tiller at 40 DAS. L2= leaf below leaf 1 . L3=leaf below leaaf 2 .

c) In each column under each environmental condition, means of any two leaf positions followed by a common letter are not significantly different at $5 \%$ level by LSD.

The difference was significant, but the general disease reactions were the same (Table 4).

\section{Ages of the plants}

Four rice cultivars were evaluated for their reaction to strain PXO82, virulent to rice genotype with $\mathrm{Xa4}$ for resisistance, at $23,30,37$, and 42 days after sowing (DAS). IR8, the susceptible cultivar, was not tested at 23 and 37 DAS because it was highly susceptible. Lesion length decreased on all the 4 rice cultivars when the plants become older (Table 6). The lesions on IR1545 and DV85 were shorter at 42 DAS than at 23 DAS. The decrease, however, was not significant, and the disease reaction of the two cultivars was 
Table 5. Reactions of rice cultivars to strains of Xanthomonas campestris py. oryzae with specific virulence at different leaf positions of the rice plants at $40 \mathrm{DAS}, 14 \mathrm{DAI}$

\begin{tabular}{|c|c|c|c|c|}
\hline \multirow{2}{*}{ Cultivar } & \multirow{2}{*}{$\begin{array}{c}\text { Leaf } \\
\text { position }\end{array}$} & \multicolumn{3}{|c|}{ Lesion $(\mathrm{cm})^{\mathrm{a})}$} \\
\hline & & PX061 & PXO79 & PXO71 \\
\hline \multirow[t]{3}{*}{ IR8 } & L1 & $22.6 \mathrm{a}$ & $16.3 \mathrm{a}$ & $19.6 \mathrm{a}$ \\
\hline & L2 & $19.9 \mathrm{~b}$ & $14.4 \mathrm{~b}$ & $19.5 \mathrm{a}$ \\
\hline & L3 & $18.0 \mathrm{c}$ & $12.4 \mathrm{c}$ & $18.7 \mathrm{a}$ \\
\hline \multirow[t]{3}{*}{ IR20 } & L1 & $2.8 \mathrm{a}$ & $10.5 \mathrm{a}$ & $4.5 \mathrm{a}$ \\
\hline & L2 & $2.1 \mathrm{a}$ & $8.4 \mathrm{~b}$ & $2.8 \mathrm{~b}$ \\
\hline & L3 & $1.9 \mathrm{a}$ & $7.7 \quad b$ & $2.5 \mathrm{~b}$ \\
\hline \multirow[t]{3}{*}{ Cempo selak } & L1 & $14.6 \mathrm{a}$ & $7.5 \mathrm{a}$ & $12.5 \mathrm{a}$ \\
\hline & $\mathrm{L} 2$ & $12.3 \mathrm{~b}$ & $4.9 \mathrm{~b}$ & $11.3 \mathrm{~b}$ \\
\hline & L3 & $12.2 \mathrm{~b}$ & $4.6 \mathrm{~b}$ & $12.8 \mathrm{a}$ \\
\hline \multirow[t]{3}{*}{ IR1545-339 } & L1 & $2.1 \mathrm{a}$ & $2.2 \mathrm{a}$ & $12.3 \mathrm{a}$ \\
\hline & $\mathrm{L} 2$ & $1.5 \mathrm{a}$ & $2.0 \mathrm{a}$ & $9.9 \quad b$ \\
\hline & L3 & $1.3 \mathrm{a}$ & $2.0 \mathrm{a}$ & $8.7 \quad c$ \\
\hline \multirow[t]{3}{*}{ ARC 7060} & L1 & $3.2 \mathrm{a}$ & $2.7 \mathrm{ab}$ & $13.7 \mathrm{a}$ \\
\hline & L2 & $3.1 \mathrm{a}$ & $1.9 \mathrm{~b}$ & $12.2 \mathrm{~b}$ \\
\hline & L3 & $2.4 \mathrm{a}$ & $3.2 \mathrm{a}$ & $9.4 \mathrm{c}$ \\
\hline \multirow[t]{3}{*}{ ARC 5756} & L1 & $1.4 \mathrm{a}$ & $1.6 \mathrm{a}$ & $3.2 \mathrm{a}$ \\
\hline & $\mathrm{L} 2$ & $1.6 \mathrm{a}$ & $1.4 \mathrm{a}$ & $2.3 \mathrm{ab}$ \\
\hline & L3 & $1.1 \mathrm{a}$ & $1.4 \mathrm{a}$ & $2.1 \mathrm{~b}$ \\
\hline \multirow[t]{3}{*}{ RP291-20 } & L1 & $1.6 \mathrm{a}$ & $1.6 \mathrm{a}$ & $9.1 \mathrm{a}$ \\
\hline & L2 & $1.4 \mathrm{a}$ & $1.3 \mathrm{a}$ & $6.3 \mathrm{~b}$ \\
\hline & L3 & $1.4 \mathrm{a}$ & $1.2 \mathrm{a}$ & $5.1 \mathrm{c}$ \\
\hline \multirow[t]{3}{*}{ DV85 } & L1 & $1.1 \mathrm{~b}$ & $1.2 \mathrm{a}$ & $1.6 \mathrm{a}$ \\
\hline & $\mathrm{L} 2$ & $1.1 \mathrm{~b}$ & $0.8 \mathrm{a}$ & $1.5 \mathrm{a}$ \\
\hline & L3 & $2.3 \mathrm{a}$ & $0.8 \mathrm{a}$ & $1.3 \mathrm{a}$ \\
\hline
\end{tabular}

a) For each cultivar under each bacterial strain, means of any two leaf positions followed by a common letter are not significantly different at $5 \%$ level by LSD.

Table 6. Effect of plant ages on lesion development caused by strain PXO82 of virulence group 2 of Xanthomonas campestris pv. oryzae

\begin{tabular}{|c|c|c|c|c|c|c|c|c|}
\hline \multirow{3}{*}{ Cultivar } & \multicolumn{8}{|c|}{ Plant age (days after sowing) } \\
\hline & \multicolumn{2}{|c|}{23} & \multicolumn{2}{|c|}{30} & \multicolumn{2}{|c|}{37} & \multicolumn{2}{|c|}{$42^{b)}$} \\
\hline & $\begin{array}{l}\text { Lesion } \\
\text { (cm) }\end{array}$ & $\begin{array}{l}\text { Leaf } \\
(\mathrm{cm})\end{array}$ & $\begin{array}{l}\text { Lesion } \\
\text { (cm) }\end{array}$ & $\begin{array}{l}\text { Leaf } \\
(\mathrm{cm})\end{array}$ & $\begin{array}{l}\text { Lesion } \\
\text { (cm) }\end{array}$ & $\begin{array}{l}\text { Leaf } \\
(\mathrm{cm})\end{array}$ & $\begin{array}{l}\text { Lesion } \\
\text { (cm) }\end{array}$ & $\begin{array}{l}\text { Leaf } \\
(\mathrm{cm})\end{array}$ \\
\hline IR8 & -c) & 一 & $24.7 \mathrm{a}$ & 25.3 & -d) & - & $17.3 \mathrm{~b}$ & 38.5 \\
\hline IR20 & $15.5 \mathrm{~b}$ & 15.6 & $11.2 \mathrm{ab}$ & 13.3 & $12.2 \mathrm{ab}$ & 19.6 & $9.3 \mathrm{a}$ & 24.9 \\
\hline IR1545-339 & $3.6 \mathrm{a}$ & 17.7 & $2.3 \mathrm{a}$ & 20.5 & $2.6 \mathrm{a}$ & 22.7 & $1.8 \mathrm{a}$ & 29.7 \\
\hline DV85 & $1.7 \mathrm{a}$ & 23.4 & $0.9 \mathrm{a}$ & 28.1 & $0.9 \mathrm{a}$ & 33.3 & $0.6 \mathrm{a}$ & 43.8 \\
\hline
\end{tabular}

a) For each cultivar, means of lesion length followed by a common letter are not significantly different at $5 \%$ level by LSD.

b) Late tillering to maximum tillering stage of the 4 cultivars in greenhouse condition at IRRI.

c) Kresek.

d) Not tested because of its susceptibility to the strain at the stage of early trial. 
Table 7. Effect of plant age of rice cultivars on lesion development caused by strain PXO79 of virulence group III of Xanthomonas campestris pv. oryzae

\begin{tabular}{|c|c|c|c|c|c|c|}
\hline \multirow{3}{*}{$\begin{array}{c}\text { Cultivar } \\
\text { ARC } 6076\end{array}$} & \multirow{3}{*}{$\begin{array}{c}\begin{array}{c}\text { Leaf } \\
\text { position }\end{array} \\
\text { LI }\end{array}$} & \multicolumn{5}{|c|}{ Lesion $(\mathbf{c m})^{b)}$} \\
\hline & & \multicolumn{2}{|c|}{ 30DAS } & \multicolumn{2}{|c|}{ 60DAS } & 90DAS ${ }^{2)}$ \\
\hline & & 26.3 & $\mathbf{a}$ & 13.7 & $\mathbf{b}$ & 9.4 \\
\hline & L2 & $20.6^{* *\left(*_{e}\right)}$ & a & $16.9^{* *}$ & b & $8.4^{* *} \mathrm{c}$ \\
\hline \multirow[t]{2}{*}{ Djawa Srie } & $\mathbf{L I}$ & 8.3 & $\mathbf{a}$ & 3.1 & b & $1.0 \mathrm{~b}$ \\
\hline & $\mathrm{L} 2$ & $11.0^{* *}$ & $\mathbf{a}$ & $2.9^{\mathrm{ns}}$ & b & $1.0^{\mathrm{ng}} \mathrm{b}$ \\
\hline \multirow[t]{2}{*}{ K116 } & $\mathbf{L} 1$ & 13.1 & a & 8.9 & b & $11.4 \mathrm{ab}$ \\
\hline & L2 & $10.7^{* *}$ & a & $6.4^{* *}$ & b & $10.7^{\mathrm{ng}} \mathrm{ab}$ \\
\hline \multirow[t]{2}{*}{ IR22 } & $\mathbf{L} \mathbf{1}$ & 19.0 & $\mathbf{a}$ & 14.3 & b & $13.0 \quad b$ \\
\hline & L2 & $16.2^{* *}$ & a & $12.4^{* *}$ & b & $13.4^{\mathrm{ng}} \mathrm{b}$ \\
\hline \multirow[t]{2}{*}{ IR8 } & L1 & 20.6 & $\mathbf{a}$ & 16.9 & b & 9.3 \\
\hline & L2 & $17.1^{* *}$ & a & $14.8^{* *}$ & & $8.4^{* *} \mathrm{~b}$ \\
\hline
\end{tabular}

a) Booting stage.

b) In a row, means followed by a common letter are not significantly different at $5 \%$ level by LSD.

c) **, ns: L2 is significantly, not significantly different from L1 at $1 \%$ level, respectively.

Table 8. Relations of overall resistance (I) and adult plant resistance (IV) groups to bacterial blight infection. Greenhouse, IRRI. Dry Season, 1978

\begin{tabular}{|c|c|c|c|c|c|c|c|c|c|c|}
\hline \multirow{3}{*}{ Variety } & \multirow{3}{*}{$\begin{array}{l}\text { Resistance } \\
\text { group }\end{array}$} & \multicolumn{9}{|c|}{ Lesion $(\mathrm{cm})$} \\
\hline & & \multicolumn{3}{|c|}{40 DAS $^{a}$} & \multicolumn{3}{|c|}{60 DAS } & \multicolumn{3}{|c|}{80 DAS $^{b)}$} \\
\hline & & PX061 & PX079 & PX071 & PXO61 & PX079 & PXO71 & PXO61 & PXO79 & PX071 \\
\hline IR1545 & I & 2.7 & 3.8 & 27.0 & 1.9 & 3.4 & 16.0 & 4.1 & 4.8 & 18.2 \\
\hline DV85 & I & 2.9 & 4.0 & 2.9 & 3.0 & 2.2 & 1.9 & 2.1 & 2.2 & 2.0 \\
\hline IR1695 & IV & 19.9 & 16.3 & 23.3 & 16.9 & 13.3 & 21.0 & 9.8 & 3.6 & 5.6 \\
\hline IR944 & IV & 25.8 & 24.0 & 23.4 & 13.4 & 20.9 & 18.0 & 6.4 & 9.6 & 11.0 \\
\hline
\end{tabular}

a) DAS=days after sowing.

b) Infection of flag leaves only.

resistant. On IR20, the disease score decreased from 9 (very susceptible) at 23, 30, and 37 DAS to 7 (susceptible) at 42 DAS. The lesion length was also significantly decreased. Even on IR 8, the lesion decreased considerably but the overall disease rating was 9 .

Five selected rice cultivars with leaf positions, one and two were evaluated at 30,60 , and 90 DAS using strain PXO79, virulent to $\mathrm{Xa4}$ for resistance. Lesion length varied with leaf positions. Shorter lesion lengths were observed on IR8 and ARC 6076 at 90 DAS than at 30 DAS (Table 7). A similar trend was noted for IR22 with Xa4 for resistance. The lesion lengths at 60 and 90 DAS on Djawa Srie of Indonesia origin were shorter than that at $30 \mathrm{DAS}$; the disease reaction also became resisant. On other cultivars, lesion length decreased but the disease reaction shifted only from very susceptible to susceptible (Table 7). 


\section{Effect of plant age and inoculum density on rice of different resis- tance}

Rice cultivars, IR1545 and DV85 with specific genes $x a 5$, and $x a 5$ and $X a 7$, respectively for resistance, and IR1695 and IR944 with specific resistance ( $\mathrm{Xa6}$ ) but functional only at the adult plants (flag leaves) to bacterial blight ${ }^{8)}$ in the Philippines were evaluated at three ages for reactions to three strains which exemplified specific virulence. Drastic difference in disease reaction was not observed on IR1545 and DV85. Lesion development of IR1545, susceptible to strain PXO71 was reduced considerably at flag leaves or on leaves of plants at 60 days old than at 40 days old. Both cultivars were resistant to the other two strains, PXO61 and PXO79. The disease reaction as well as lesion length was not affected (Table 8). Cultivar IR1695, which inherited its resistance from Zenith, and IR944 from Malagkit Sungsong, whose adult plant resistance is expressed on flag leaves, showed significant lesion reduction as well as disease reaction when infection against the strains was initiated in older plants (Table 8). At 40 DAS (tillering stage), plants of rice cultivars having adult plant resistance revealed a distinct susceptible reaction with uniformly long lesions, but at 90 DAS (flag leaf stage), they became more resistant.

When seven rice cultivars with different resistance genes were evaluated at 40 DAS against virulence group 1 strain PXO61 at two inoculum dosages, $10^{8}$ cells $/ \mathrm{ml}$ and $10^{6}$ cells/ ml, lesion development was reduced at low dosage (Table 9). Cultivars such as Pulo and Sailboro 302 with intermediate reaction to the strain, showed a shorter lesion than IR8, the susceptible check at both high and low dosages. Since IR20 and IR1545 had resistance to the strain, no visible infection was observed at 14 days after infection at low dosage (Taleb 9). The disease based on lesion length of IR8, although shorter at low than at high dosage, changed only from very susceptible to susceptible reaction, and the color of the infected tissue was water-soaking with greyish color.

\section{Discussion}

The general trend of rice cultivars such as IR8, IR20 and IR1545 having susceptibility and resistance to the three bacterial strains was found independent from methods of inoculation. The major difference was noted only on incubation period. The spray method of inoculation usually yielded a longer incubation period. This could be due to the actual amount of inoculum deposited at the infection court which was considerably smaller than those of clipping or pin-pricking methods of inoculation. On these latter methods, the inoculum was directly introduced into the infection court, i. e. the vascular elements. Subsequently, all other results reported in this paper were based on the leaf clipping 
method of inoculation.

Rice cultivars or breeding lines derived from the same resistance donor responded similarly to strains of the bacterial pathogen in the same virulence group at the maximum tillering stage (Table 2). Although minor variation was noted, the overall disease reaction was consistent. No complete resistance was found in lines or cultivars derived from TKM 6 for $X a 4$ and DZ192 for $x a 5$. The distinction of the two sources responding differentially to the two groups of bacterial strains was anyhow, clearcut and confirmed early reports ${ }^{9}$.

On this basis, leaves of individual plants or tillers at different positions denoting varying leaf age were further analyzed for infection to strains having specific virulence. The lesion development on fully expanded leaves of IR8, IR40 (conferring the same genetical background as IR20 for resistance to bacerial blight) and IR1545, was not affected by their ages but was affected by strains virulent to the cultivars (Table 3). Older or lower leaves showed slightly shorter lesion as compared to younger or upper leaves of a plant or tiller, but the difference was seldom significant and the overall disease reaction of individual leaves was the same in all positions (Table 3) at the same age, i. e., tillering or maximum tillering stage. Similar results also were obtained when plants were grown in an environmentally controlled room (Table 4). The results confirmed an earlier study that, although resistance in rice conferring $X a 4$ or $x a 5$ for resistance was incomplete at a younger growth stage, the differential interaction was not affected by the growth conditions and the growth stage ${ }^{\text {g) }}$ nor by the leaf position (Table 5).

When plants at different ages, i. e., days after sowing: were evaluated against strain PXO82, virulent to IR8 and IR20 but avirulent to IR1545 and DV85, the resistance of the latter two cultivars was consistent throughout the ages of the plants tested (Table 6). The lesion size of the cultivars susceptible to the strain was proportional to plant age, but susceptibility was comparable. Ezuka et al. ${ }^{4}$ ) indicated difference in resistance expression to $X$. campestris pv. oryzae between seedlings and adult plant stages of Wase Aikoku group of rice cultivars, i. e. the resistance was complete (clearcut resistance) at reproductive stages and presumably on flag leaves. We assumed that there was completeness of the resistance although varied, but differential interactions between the cultivars and bacterial strains could be again tested if true adult plant resistance is to be ascertained. Our results showed that cultivars such as IR1695 and IR944 were resistant at flag leaf stage but susceptible to all strains at tillering and maximum tillering stages (Table 8 ), indicating adult plant resistance. The response of these cultivars to strain PXO61 was similar to IR8 at lower inoculum dosage $\left(10^{6}\right.$ cells $\left./ \mathrm{ml}\right)$; the lesion size was also reduced considerably but the disease reaction was still susceptible. On the other hand, cultivars such as IR20 and IR1545 which are resistant to the strain remained resistant (Table 9). Likewise, the reaction of some selected rice cultivars such as IR20 and IR8 to infection by PXO79, was quite uniform regardless of leaf positions and plant ages.

It therefore suggests that rice varieties, in order to serve as differentials for $X$. campestris pv. oryzae, should have consistent reactions to infection. The lesion size may be reduced slightly as plants become mature, but the reaction of a cultivar having specific resistance to a strain of the pathogen was not significantly affected regardless of leaf posions and plant ages. The differential interaction was revealed whether or not the resistance was complete. 


\section{Literature cited}

1. Ezuka, A. and Sakaguchi, S. (1978). Plant Prot. Res. 11 : 93-118.

2. Ezuka, A., Horino, O., Toriyama, K., Shinoda, H. and Morinaka, T. (1975). Bull. Tokai-Kinki Natl. Agric. Exp. Stn. 28: 124-130.

3. Ezuka, A. and Horino, O. (1974). Ibid. $27: 1-19$.

4. Ezuka, A., Watanabe, Y. and Horino, O. (1974). Ibid. $27: 20-25$.

5. Gomez, K. A. and Gomez, A. A. (1976). Statistical Procedures for Agricultural Research with Emphasis in Rice. International Rice Researh Institute, Los Baños, Philippines. 294 p.

6. Horino, O. and Yamada, T. (1979). Proc. Assoc. Plant Prot. Hokuriku 27: 12-18 (in Japanese with English summary).

7. International Rice Research Institute. (1975). Standard Evaluation System for Rice. Los Baños, Philippines. pp. 36-37.

8. International Rice Research Institute. (1979). Annual Report for 1978. IRRI. Los Baños. Philippines.

9. Mew, T. W. and Vera Cruz, C. M. (1979). Phytopathology $69: 152-155$.

10. Ogawa, T., Morinaka, T., Fujii, K. and Kimura, T. (1978). Ann. Phytopath. Soc. Japan 44 : 137-141.

11. Ou, S. H. (1972). Rice Diseases. Commonwealth Mycological Institute, Kew, England. 367 p.

12. Petpsist, V., Khush, G. S. and Kauffman, H. E. (1977). Crop Sci. 17 : 551-554.

13. Sidhu, G. S. and Khush, S. G. (1978). Phytopathology $68: 461-463$.

14. Sidhu, G. S., Khush, G. S. and Mew, T. W. (1978). Theor. Appl. Genet. $53:$ 105-111.

15. Van der Plank, J.E. (1968). Disease Resistance in Plants. Academic Press, New York. 206 p.

16. Wakimoto, S. (1954). Bull. Fac. Agr., Kyushu Univ. 14:475-477.

\section{和 文 摘 要}

\section{白葉枯病に対するイネ品種の抵抗性発現の変動}

\section{T. W. Mew - C. M. Vera CRUz - R. C. Reyes}

イネ品種，IR8，IR20，IR1545に Xanthomonas campestris pv. oryzae の菌怢を咅葉接種法，針接種法 および噴䁶接種法によって接種し，発病度を調べた結果，供試品種について接種法の違いによる病斑長と発 病度に明らかな差異はなかったが，潜伏期間には差異がみられた。最高分けつ期に本病抵抗性遗伝子，Xa 4 をすつ TKM6 ならびにそれに由来する系統，およびXa5 をむつDZ192 ならびにそれ机由来する采統の 発病度は同し病原性群内の菌株間で差異がなかった。TKM6 に由来する系統に対する病原性群 1 と病原性 群 2 の病原性には顕著な差異が認められたが，DZ192 に由来する系統に対する両病原性群の病原性の間に は差異はなかった。異なる葉位扣よび異なる生育時期の発病度を調べた結果, 葉身展開後の経過日数ならび に生育時期が進むにつれて，発病度は低くなる傾向を示し，とくにこの頃向はイネ品種・病原性群の親和性 組合せに执いて顕著であった。IR1695 および IR944のような成体抵抗性（adult plant resistance）をむ つ系統の供試全菌株に対する発病度は，栄盖生長期から生殖生長期に進むにつれて徐々に低下した。部分的 抵抗性（partial resistance）をむつとみなされている中程度の抵抗性を示す品種の病斑長は，接種菌濃度かi 低い場合沉著しく短くなった。一方，成体抵抗性をるつ系統の接種菌浱度の低下による病斑長の変化は，感 受性の対照品種として用いた IR8 と同様の傾向を示した。 